\title{
Mapping Environmental/Sustainable Governance Research in Chile: A Bibliometric and Network Analysis
}

\author{
Julien Vanhulst ${ }^{1}\left(\mathbb{D}\right.$ and Adrián E. Beling ${ }^{2,3, * \mathbb{D}}$ \\ 1 Social Sciences Department, Universidad Católica del Maule, Talca 3460000, Chile; julien@ucm.cl \\ 2 Global Studies Programme, FLACSO, Buenos Aires C1050AAN, Argentina \\ 3 Institute of Asian and African Studies, Humboldt University of Berlin, 10115 Berlin, Germany \\ * Correspondence: abeling@flacso.org.ar
}

Citation: Vanhulst, J.; Beling, A.E. Mapping Environmental/Sustainable Governance Research in Chile: A Bibliometric and Network Analysis. Sustainability 2021, 13, 6484. https:// doi.org/10.3390/su13116484

Academic Editor: Colin Michael Hall

Received: 13 April 2021

Accepted: 2 June 2021

Published: 7 June 2021

Publisher's Note: MDPI stays neutral with regard to jurisdictional claims in published maps and institutional affiliations.

Copyright: (c) 2021 by the authors. Licensee MDPI, Basel, Switzerland. This article is an open access article distributed under the terms and conditions of the Creative Commons Attribution (CC BY) license (https:/ / creativecommons.org/licenses/by/ $4.0 /)$.

\begin{abstract}
In light of increasing concerns about the efficacy of environmental governance (EG) to address the global sustainability challenges of the Anthropocene era, more integrative, transversal, and far-reaching approaches, referred to here as sustainability governance (SG), are gaining ground both in governance praxis and in research. Empirical and methodological challenges emerge from this conceptual analytical cleavage between EG and SG. Through a combination of bibliometric and network analysis, the objective of this article is to explore the structure and trends in the field of EG/SG research in Chile, internationally regarded as the posterchild of Latin-American EG/SG, and derive empirical insights to feed the analytical distinction between EG and SG that informs global debates about ways forward towards an effective governance in the Anthropocene. Our results show that scientific research on EG/SG has experienced a significant increase since the 1990s. We find that while the topical range of the field is broad, including water governance, biodiversity conservation, environmental institutions, climate change and energy issues, and environmental conflicts and justice, key cross-cutting socio-economic and cultural dynamics underpinning the prevalent, yet fundamentally unsustainable, ways of life and economic model are virtually absent from the field, against their growing presence in diagnoses of "sustained unsustainability".
\end{abstract}

Keywords: bibliometric analysis; social network analysis; environmental/sustainable governance; scientific knowledge; critical sustainability studies

\section{Introduction}

The very existence of any human collectivity entails the addressing of problems, whose cultural and political resolution makes up the basis of the social fabric $[1,2]$. In the 1990s, the concept of "governance" was coined to account for the modes of response to these problems [3]. Governance encompasses a broad set of entities and phenomena and refers to the processes of decentralizing authority in order to define social problems and responses within a context of growing diversity and complexity in society [4-6]. Thus, it seeks to account for the hybridization of all kinds of efforts to govern the res publica by different socio-political actors (public and private, each oriented by their own interests and rationalities) on different geographical scales [3].

Traditionally in social theory, at the core of governance processes was the issue of intrasocial and inter-social cohesion (internal order, socialization, relations between collectivities, etc.). However, during the late 20th century, with the increasing awareness of the impacts of human activities on natural ecosystems, the relation between human societies and their ecological environment gradually entered the sphere of governance, as attested by an exponential increase in environmental accords, norms, and regulations at the diverse levels of sub-, supra- and trans-national governance $[4,7,8]$.

In retrospect, the problem of socio-ecological sustainability can be said to have entered the sphere of politics in the 1970s $[9,10]$. The "Great Acceleration" observed since the mid20th century [11] - that is, the generalization of ecologically unsustainable exponential 
growth-trends in virtually all areas of human activity, with its concomitant impact on local and global ecosystems-has implied that, while conventional environmental problems such as water or air pollution remain important issues in many local settings, global or "earth-system" ecological change processes progressively took center stage. Thus, socioecological sustainability has become a new problem of collective life on a planetary scale, insofar as the future of many forms of life on Earth (including that of human beings), as well as a certain dynamic balance of bio-geo-chemical systems that are being fundamentally disrupted, depend on the regulation of the social world, as implied in the idea of the "Anthropocene" [12-14].

A key distinction is required at this point between 'lifeworld' and 'system' sustainability. The "environmental state" and governance structures that took shape since the 1970s are set up to create (if successful) an environmentally sustainable lifeworld, with little regard for the fact that globally hegemonic ways of life are predicated, however, on a fundamentally unsustainable reproductive system [15]. A comprehensive transition to systemic sustainability, on the other hand, will require deep changes in the lifeworld. In accordance with this distinction between lifeworld sustainability and systemic sustainability, and for the analytic purposes of this article, we will distinguish between two concepts of governance: "environmental governance" (EG) and "sustainability governance" (SG). More specifically EG refers to "the set of regulatory processes, mechanisms and organizations through which political actors influence environmental actions and outcomes" [6], often involving negotiated interactions and participatory processes encompassing a broad range of actors (public authorities, organized groups, market actors, civil society) [16]. EG is typically (though not necessarily) short term, reactive in character, and addresses discrete socio-environmental problems within specific spatiotemporal coordinates. By contrast, SG refers to the steering of social change as it intersects with environmental changes, and vice versa, and is typically long term, integrative, and addresses diffuse and transversal issues $[7,15]$. The neat conceptual distinction drawn here between SG (system sustainability) and EG (lifeworld sustainability) is not matched by equal clarity in the literature, however, where the prevailing terminology tends to hybridize both accounts, including "sustainability governance" [4,7,17], "socio-ecological governance" [5,18],"environmental governance" [6,19], and even Earth-system governance [20].

EG/SG correspond to concrete answers implemented by society based on the process of reflection (approaches/discourses) triggered by the recognition of ecological conditions and changes (diagnosis). Since the environment entered the political arena in the 1960s-70s, voices raising alarm regarding the state of ecological systems keep multiplying, both in the social and in the scientific sphere (IPCC Assessment Reports, Millennium Ecosystems Assessment, Global Environment Outlook, among others). In parallel, a global loosely networked system of EG/SG has been established, including international, national and local platforms (with institutions, plans, laws, strategies, etc.), and citizen initiatives for sustainability have swarmed [8]. The state of the planetary biosphere has continued to decline, often at an accelerating pace (see, i.e., [21]). What used to be conceived of in terms of a global environmental crisis is increasingly reframed as an ecological crisis [8] - that is, a crisis of relationality, where environmental issues cannot be meaningfully addressed as separate from the technoeconomic and sociocultural matrix underpinning individualistic, resource-intensive ways of life which have been rapidly spreading across the planet since the last decades of the past century $[22,23]$.

Correspondingly, EG/SG has become the object of study of academic researchers crossing multiple disciplines that seek to understand and assess the manifold interventions undertaken to change our values, behavior, and reconfigure our practices and institutions. The objects of EG/SG research are the processes and patterns that emerge from governance activities performed by diverse actors at all levels of decision-making (including governments but also non-state actors such as business, NGO and citizenry) in order to respond to the problems of socio-ecological sustainability. For example, at international level, EG/SG research focuses on multinational institutions (such as the UN or OECD) 
(i.e., [24-26]) or on international agreements (for example climate or biodiversity agreements but also trade agreements) (i.e., [27-29]). At national level, in turn, work on EG/SG focuses on the design and implementation of environmental policies and regulations, environmental institutions, interface between science and policy, inclusion of civil society or private actors, among others. At the micro-level, research on EG/SG focuses on social transition initiatives, such as alternative food networks, renewable energy communities, modes of consumption, or commons governance. Yet as the Anthropocene is characterized by complex socio-ecological dynamics, research on EG/SG is constantly evolving to help understand what kind of responses and political strategies would be most appropriate and effective to ensure systemic sustainability.

Worldwide there is an exponential growth of research and literature on EG/SG calling for new strategies capable of dealing with large amounts of information. In this context, the contribution of this paper is twofold. First, on the methodological front, the combination of bibliometric and network analysis of a large corpus of data allows for both a synchronic (mapping) and diachronic structuring of the research field on EG/SG, accounting for the identification of topical foci, dimensions, actors, patterns of inter-disciplinary collaboration, etc. Secondly, by focusing on the Chilean field of EG/SG research, this paper contributes to enlarging the empirical base for the conceptual distinction between EG and SG, including the global South. Moreover, Chile being internationally regarded as the posterchild of Latin-American EG/SG, our inquiry allows a glimpse into the regulative ideals in EG/SG research at a broader regional/international level, but also into topics and dimensions omitted or excluded from the field.

In line with the above, the general objective of the paper is to identify the trends and structuring patterns of academic knowledge production on EG/SG in Chile, in order to feed empirical insights into the analytical distinction between EG and SG. The paper thus builds on a double register: an empirical-descriptive and a critically aimed conceptual-analytic one, with the latter drawing on the former. Accordingly, our study sought to answer the following questions:

(RQ1) What are historical trends of academic production on EG/SG in Chile?

(RQ1a)When does this area of study appear in Chile and how is it evolving?

(RQ1b)What are the main topics covered by scientific production and how do they evolve and change over the time?

(RQ2) Who are the most influential actors, research centers and communities, articles and journals that participate in the production and circulation of academic knowledge on EG/SG in Chile?

(RQ3) How are the interactions among (collective) actors participating in knowledge production on EG/SG in Chile configured?

(RQ3a) What scientific communities can be identified based on the analysis of interactions among actors in the network?

(RQ3b)What attributes of the actors (cognitive, institutional, and disciplinary) allow us to understand the structure of their interactions?

(RQ3c) How are the dynamics of interdisciplinary and inter-institutional collaboration configured in the interaction network?

This paper is organized as follows. Section 2 describes the material and methods. The research results and analyses are presented in Section 3. Section 4 offers some threads for discussion, and Section 4 reaches some conclusions.

\section{Materials and Methods}

The insights we sought to derive about EG/SG research where drawn from the study of academic production through the method of network analysis [30,31], based on the tools of bibliometrics [32]. Bibliometric analysis allows us to grasp the main characteristics and trends in a given research field through the analysis of a large amount of historical literature data. For the present study, we performed a query in the WoS, Scopus, Research 
Gate, Academia.edu and Google Scholar databases during December 2018. Three selection criteria were applied: (1) original article or book chapter (thus excluding books and grey literature) in English or Spanish, (2) published before 2018, and (3) referring to EG/SG in Chile. The search protocol applied is summarized in Table 1.

Table 1. Search protocol.

\begin{tabular}{cc}
\hline Criteria & Details \\
\hline Timespan & $\ldots-2018$ \\
Document Types & Article, Book Chapter \\
Databases & WoS, Scopus, Research Gate, Academia.edu and Google Scholar \\
Tields & Topic (title, abstract, keywords) \\
& (Gobernanza Ambiental/Environmental Governance/Gobernanza \\
& $\begin{array}{c}\text { para la Sustentabilidad/Sustainability Governance/Política Pública } \\
\text { medio ambiente/Public Policy Environment/Public Policies } \\
\text { Key-terms }\end{array}$ \\
& Environment/Política medio ambiente/Environmental Policy) \\
& AND (Chile) \\
\hline
\end{tabular}

The query returned 236 documents published between 1993 and 2018 (henceforth, referred to as data set) by a total of 449 authors and covering twenty different topics: Air, Water, Aquatic ecosystems, Biodiversity, Climate change, Energy, Environmental education, Environmental governance, Environmental Policies \& Laws, Global change, Forests, Hydroelectricity, Mining, Public policies, Social movements, Risk, Sustainable agriculture, Sustainable cities, Tourism and Management of waste. These topics refer to the subjects analyzed through EG/SG lens. Some include the problem of governance itself as a central theme of analysis (particularly the topic "Environmental Policies \& Laws", which is one of the most important topics; others analyze more particularly the governance of certain areas of sustainability, such as air, water, biodiversity, climate change, etc. We found that the structure of the scientific landscape of EG/SG in Chile strongly depend on these topics. It is these topics (together with institutional affiliation) that allow us to explain the interactions between the actors

We used the following information from the data set to build a database of the academic production of research on EG/SG in Chile. First, we systematized data on authors, title, journal, year of publication, and keywords. We also added data on the topics covered (inferred from the reading of the abstracts or of the full text). Secondly, we drew all the information contained in the bibliographic references: cited authors, document title and type (article, book, chapter, letter, law, thesis, report, etc.), journal, year of publication, and country of the journal or publisher. From this database, we built different kinds of networks with GEPHI software (https: / / gephi.org/, accessed on 2 June 2021) (keywords association network, citations networks and collaboration networks). In addition, we collected a series of attributes associated with the actors of the network: gender, disciplinary background, and institutional affiliation in order to carry out qualitative analysis of the structure of the networks. Table 2 summarizes the data and method used to cover the research questions.

Table 2. General data and methods used relating to the research questions.

\begin{tabular}{lll}
\hline $\begin{array}{l}\text { Research } \\
\text { Question }\end{array}$ & Data & Method \\
\hline RQ1a & General database & Statistical analysis \\
RQ1b & General database & Statistical analysis \\
& Keywords co-occurrence matrix & Keyword associations network \\
\hline
\end{tabular}


Table 2. Cont.

\begin{tabular}{|c|c|c|}
\hline $\begin{array}{l}\text { Research } \\
\text { Question }\end{array}$ & Data & Method \\
\hline RQ2 & $\begin{array}{l}\text { Citations matrix from entire data set } \\
\text { (weighted according to the number of } \\
\text { authors of the citing text, to avoid } \\
\text { duplication of references) } \\
\text { Citations matrix among the } 449 \text { authors } \\
\text { of the data set (weighted according to the } \\
\text { number of authors of the citing text so } \\
\text { one reference remains one reference and } \\
\text { is not multiplied) } \\
\text { Paper-to-paper citations matrix from the } \\
\text { references of the whole corpus } \\
\text { Paper-to-paper citations matrix among } \\
\text { the articles of the data set. }\end{array}$ & $\begin{array}{l}\text { Citations network } \\
\text { Square citations networks } \\
\text { Paper-to-paper network } \\
\text { Square paper-to-paper network }\end{array}$ \\
\hline $\begin{array}{l}\text { RQ3a } \\
\text { RQ3b } \\
\text { RQ3c }\end{array}$ & $\begin{array}{l}\text { Co-authorship matrix } \\
\text { Citations matrix }\end{array}$ & $\begin{array}{l}\text { Collaboration Network Analysis } \\
\text { Citations Network } \\
\text { Network nodes attributes analysis }\end{array}$ \\
\hline
\end{tabular}

\section{Results}

\subsection{Statistics from the Data Set}

Figure 1 shows the evolution of publications on EG/SG in Chile between 1993 and 2018. The results show a significant increase in the overall academic production on EG/SG in Chile since the 1990s, notwithstanding the more recent appearance of some topics such as energy, hydroelectric power, or global change (see Figure 2). In the last ten years, the number of publications has roughly quadrupled. This tendency indicates a growing academic interest in this field of research, concomitant with the progressive strengthening of the institutional framework and of the endowment for science and technology in Chile [33].

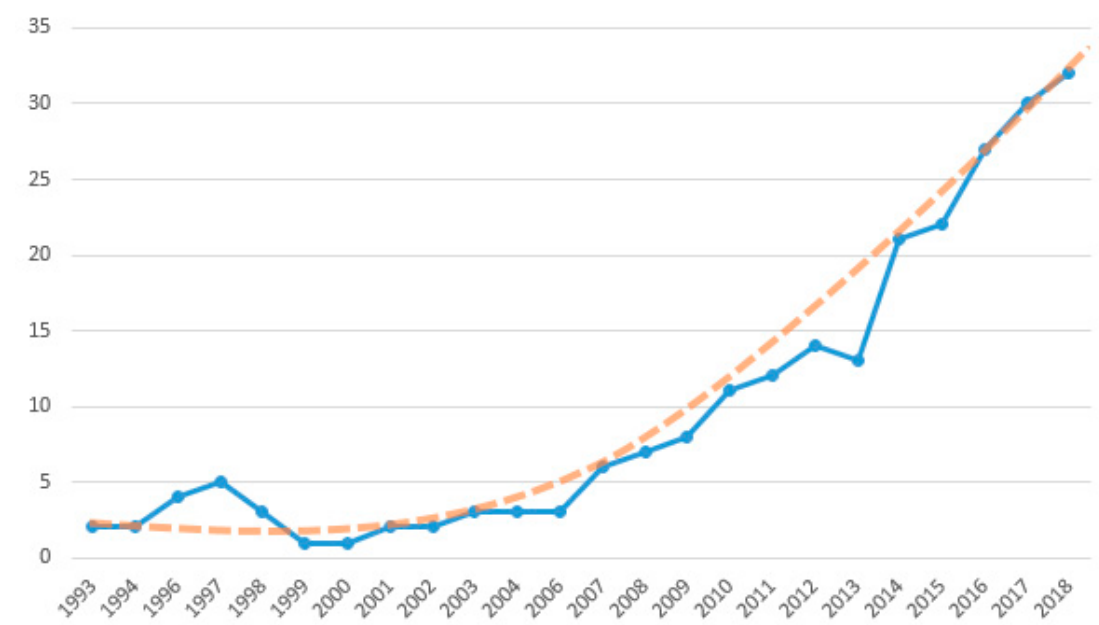

Figure 1. Publication trends by years, 1993-2018.

Considering the topics covered by the literature, we can observe specific trends (see Figures 2-4). The first trend refers to the topical foci throughout the overall period: environmental policies, laws, and regulations; aquatic ecosystems (including rivers, wetlands, lakes, and oceans and seas, but also artificial aquatic ecosystems such as salmon farms, which is a hot subtopic, as we will see); water (access, use, and legal regime, including water markets, which is a top keyword); climate change; global change (i.e., integrative studies offering an overview of socio-ecological sustainability worldwide); forests; energy (with an emphasis on hydro-energy); and biodiversity. Second observable trend: the topic 
"environmental policies and laws" is present from the beginning and remains the most important topic throughout the period, reinforced further since the end of the 2000s coinciding with the reform of environmental institutions and legislation in Chile, as per Law 20.417. In this topic, the focus is explicitly on the configuration of forms of environmental governance at a general level (including mechanisms of transparency, participation, accountability, precaution, etc.) in the Chilean political context and their limits vis-à-vis SG. The articles in this topical category adopt a very critical perspective regarding the gap between formal arrangements and actual impact in a highly centralized country with a primarily technocratic environmental policy [34] that responds to exogenous demands and standards for EG, among others from the UN and OECD [35,36] (See more details below in point 3.5. Main Research themes, which underlines the relative importance of this topic in the total data set). Biodiversity is also present from the beginning (Chile having signed and ratified the Convention on Biological Diversity in 1994) and shows a rising curve, its importance, however, decreasing with respect to other topics (see Figure 3). Aquatic ecosystems and the issue of water have also remained central since the 1990s, exhibiting a sustained increase. The topic of forests has been present to a lesser extent since the beginning of the debates on EG in Chile and continues until the 2010s. The emerging topics of energy and climate change have gained traction in the last decade (although climate change has been present more marginally since the 1990s). This is consistent with the growing global concern with climate governance (mitigation and adaptation) $[37,38]$ and, at the national level, with the inclusion of climate change as a strategic axis within the Ministry of the Environment. The topic of energy goes hand in hand with that of climate change, with a focus on renewable energy and energy transition. Finally, some topics have been relegated in importance since the 2000s: sustainable tourism, air quality, sustainable cities, mining, waste, and risk management.

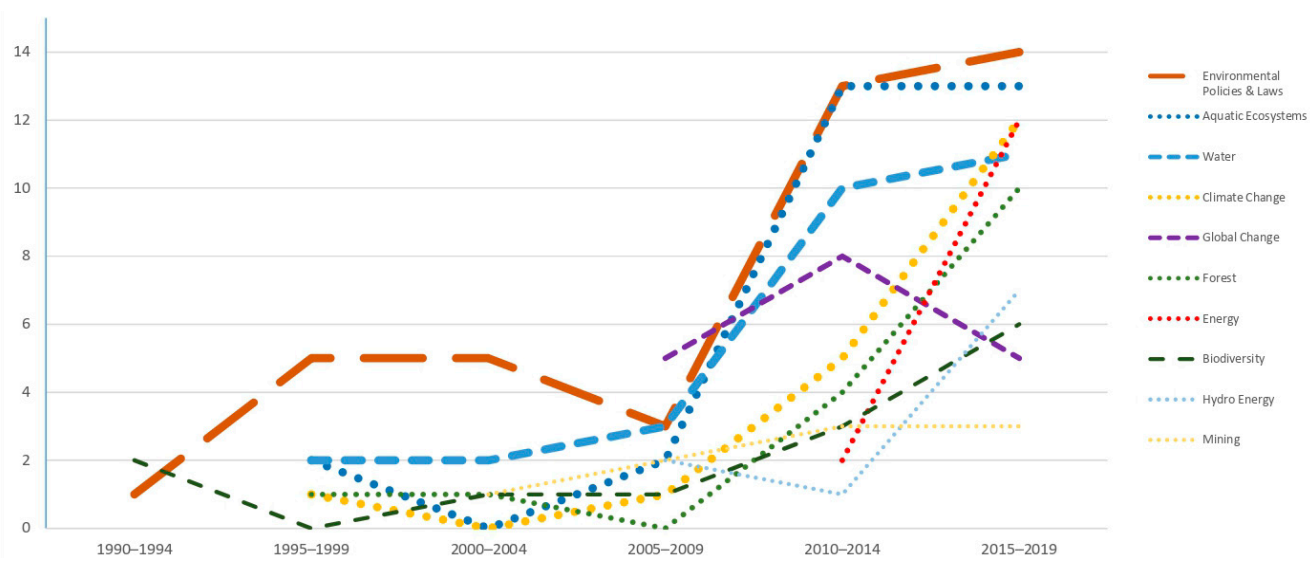

Figure 2. Topical trends by years, 1993-2018.

\subsection{Analysis of Journals}

The surveyed articles were published in 148 different journals. Table 3 shows the top 10 journals and the respective country of publication. We see a pool of four journals in first line: Geoforum; Environmental Science \& Policy; Environment, Development and Sustainability; and Sustainability. However, they cover only between $2 \%-4 \%$ of the total articles in our data set. The publications of the data set are spread among a large number of different journals, mainly from the United Kingdom (25\%), Chile (23\%), United States $(17 \%)$ and Netherlands (13\%), consistent with the centralizing pattern of global scientific publications in the global north [39-41]. 
Table 3. Top 10 journals of published articles.

\begin{tabular}{lcc}
\hline Journal & Journal Country & Articles \\
\hline Geoforum & United Kingdom & 8 \\
Environmental Science \& Policy & Netherlands & 6 \\
Environment, Development and & Netherlands & 5 \\
Sustainability & Switzerland & 5 \\
Sustainability & Chile & 4 \\
Ambiente y Desarrollo & Chile & 4 \\
EURE & Canada & 3 \\
Ecology and Society & Netherlands & 3 \\
Journal of Cleaner Production & Chile & 3 \\
Polis: Revista Latinoamericana & Chile & 3 \\
Revista Chilena de Historia Natural & United States & 3 \\
Third World Quarterly & & \\
\hline
\end{tabular}
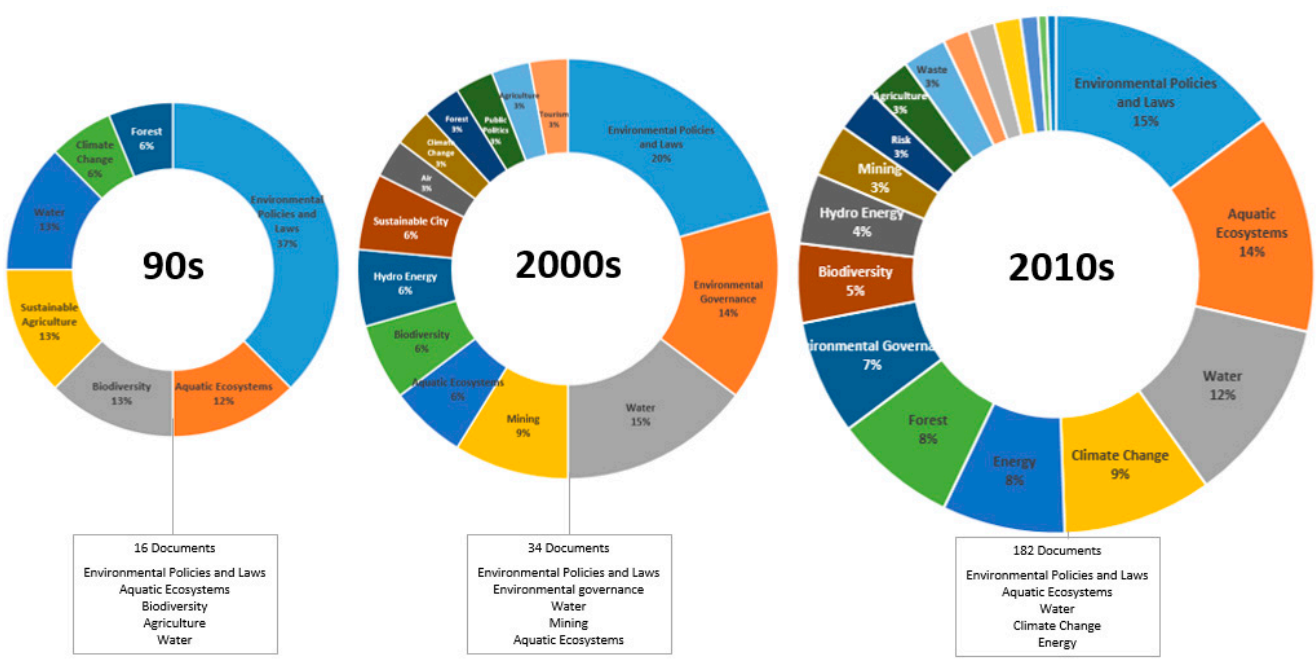

Figure 3. Topical trends by decades.

However, if we look instead at the database of citations retrieved from the corpus, we get a different picture (See Table 4 and Figure 4), namely that even though the analysis is similar in terms of country-based distribution, United Kingdom (29\%), USA (28\%), and the Netherlands (16\%) concentrate $73 \%$ of the total citation, while Chile scores fourth with only $14 \%$.

Table 4. Top 10 journals of cited articles (by weighted Indegree).

\begin{tabular}{lcc}
\hline Journal & Weighted Indegree & Journal Country \\
\hline Geoforum & 182 & United Kingdom \\
Ambiente y Desarrollo & 180 & Chile \\
Ecology and Society & 178 & Canada \\
Global Environmental Change & 178 & Netherlands \\
Science & 148 & United States \\
Ecological Economics & 144 & Netherlands \\
World Development & 112 & United Kingdom \\
Revista Chilena de Historia & 110 & Chile \\
Natural & 96 & United Kingdom \\
Energy Policy & &
\end{tabular}




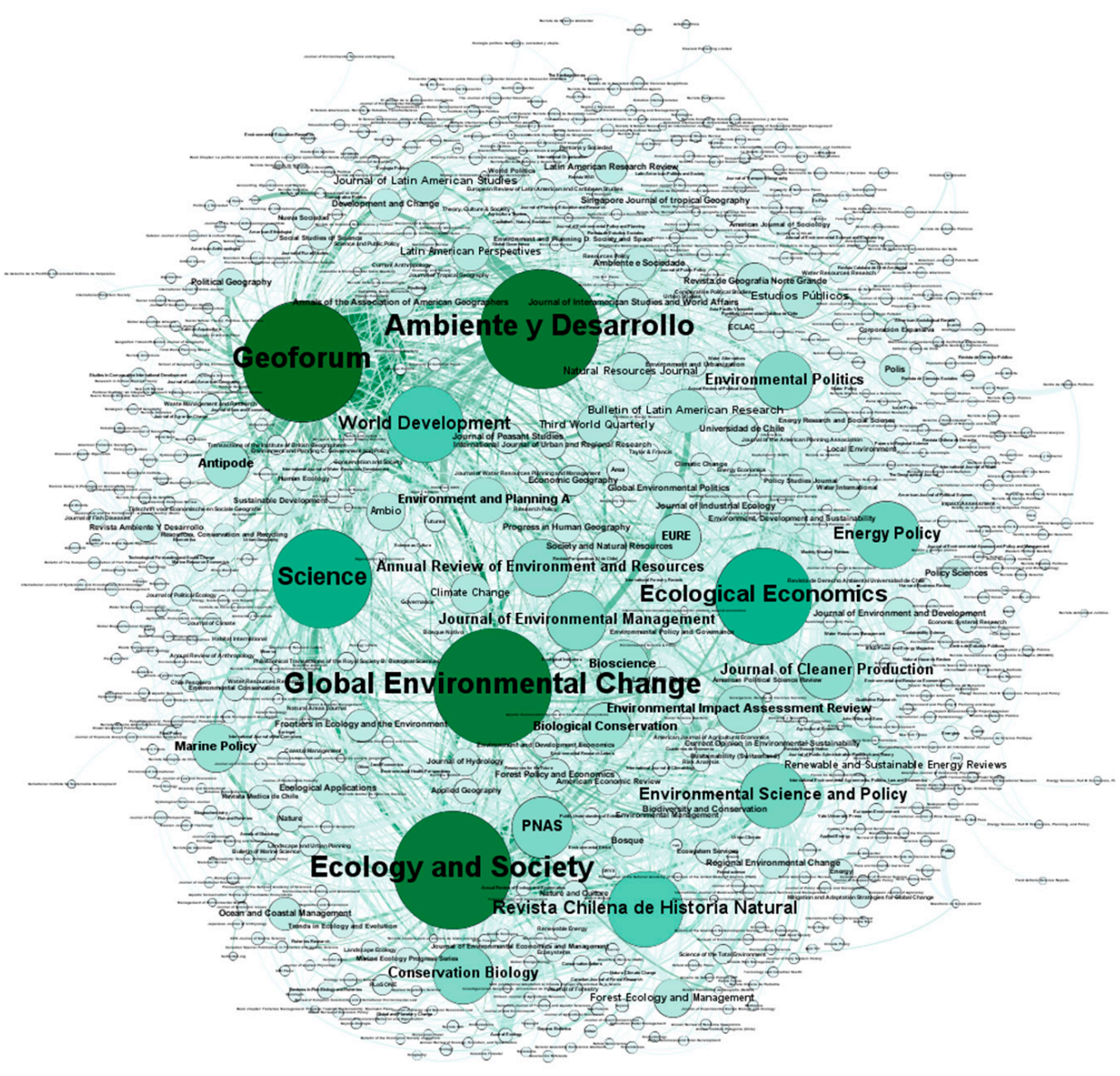

Figure 4. Network of journals based on citations database (Network built based on paper-to-paper citations, considering the journal of publication. This is a directed graph generated with the centrality and proximity algorithm Fruchterman-Reingold [42]. The size and color of the nodes varies according to Indegree (number of citations received)).

\subsection{Analysis of Academic Disciplines}

According to the OECD category scheme for R\&D [43], the main disciplines participating in academic production on EG/SG in Chile are the following: social sciences (49\%), natural sciences $(18 \%)$, engineering and technology $(17 \%)$, agricultural and veterinary sciences $(13 \%)$, and, more marginally, medical and health sciences $(2 \%)$. This result shows that, overall, EG/SG research is a multidisciplinary field, even though collaboration networks show a dialogue pattern which results in clustering around some disciplines (see Figure 5), particularly the natural and agricultural sciences with engineering, as well as single-discipline groups (from the social sciences, but also engineering). Thus, even if the social sciences appear to dominate the field with $49 \%$ of the researchers, a large number thereof are scattered, working either alone or with colleagues from within the social sciences. Disciplinary inbreeding becomes even more apparent if we focus on the citations among researchers within the data set (see Figure 6 based on square matrix of citations). We clearly see disciplinary clusters: social sciences, agricultural sciences and natural sciences clustered around some central actors in disciplinary pools, while engineering is more distributed and peripheral within the network. The collaborations network is not very dense (with a result of 0.012), which indicates little connection between the actors, and the presence of some central (more or less interdisciplinary) groups. 


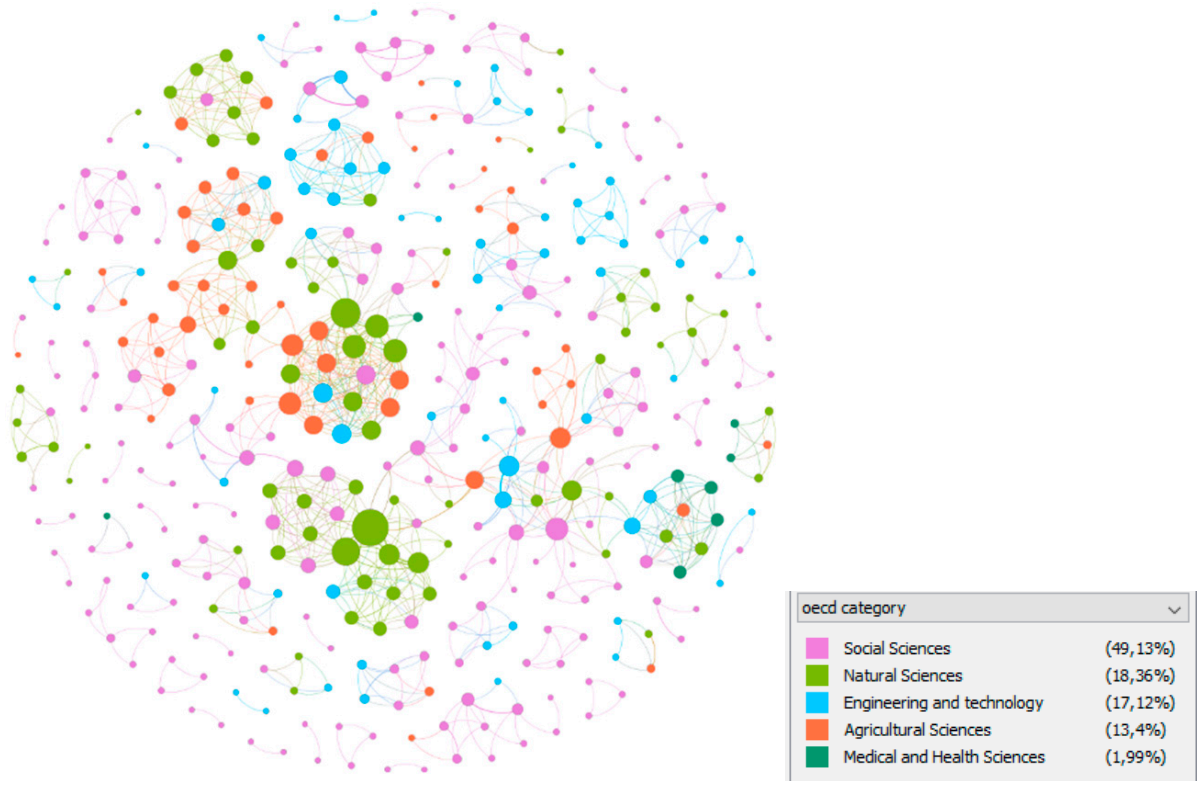

Figure 5. Collaborations Network by discipline (Network built on the basis of co-authorship of the articles in the data set. This is an undirected graph generated with the centrality and proximity algorithm Fruchterman-Reingold [42]. The size of the nodes varies according to their degree and each color represents an academic discipline).

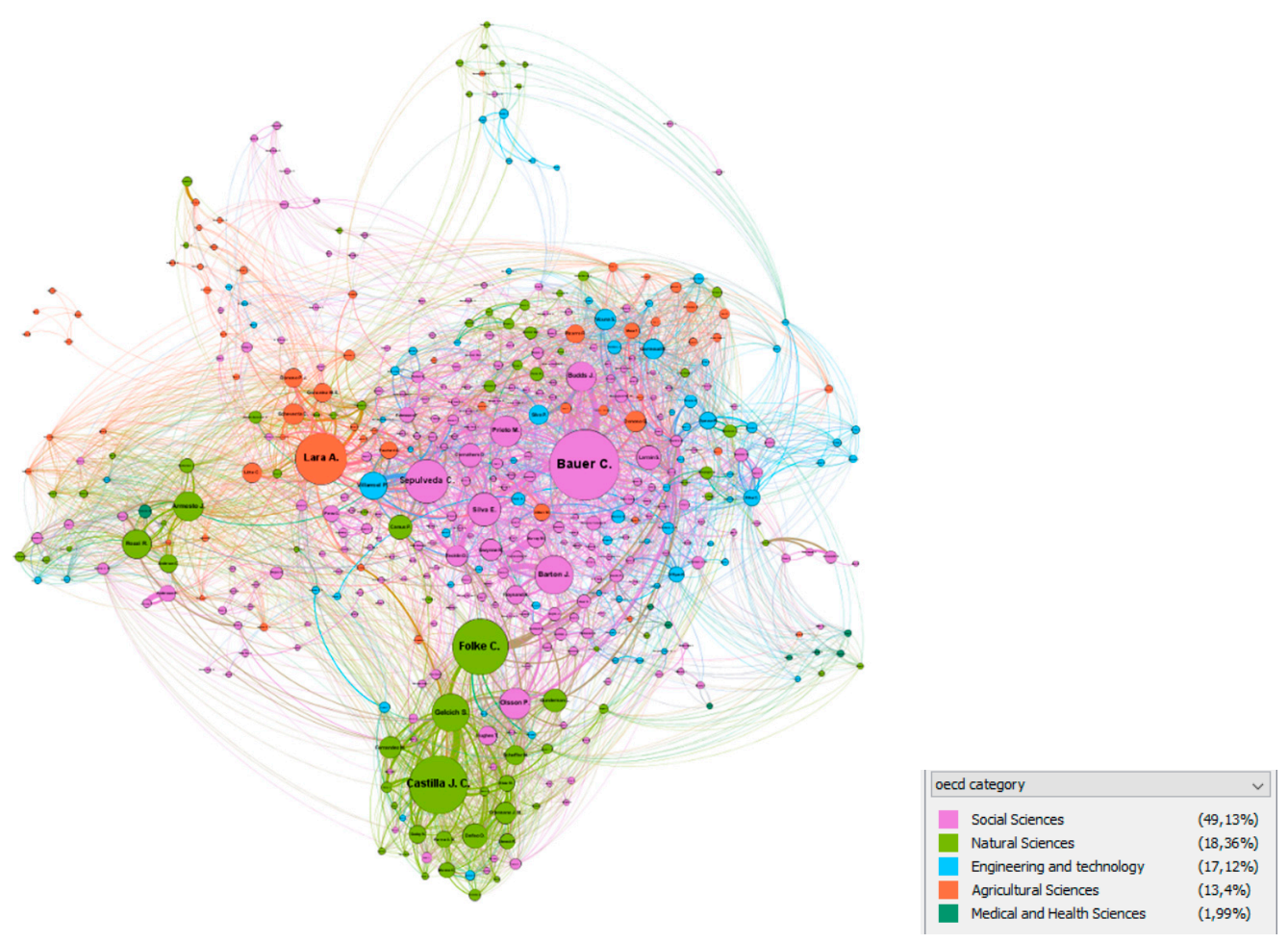

Figure 6. Square citations Network by disciplines (Network based on citations from articles to authors, both from within the data set. This is a directed graph generated with the centrality and proximity algorithm Force Atlas 2 [44]. Size and color of the nodes is analogous to the previous networks showcased).

\subsection{Analysis of Central Research Groups and Authors}

To identify central authors, we use both the network of collaborations and the network of citations, each enabling a grasp of a different pattern: first, a collective one (through 
identifying central actors within core research groups in the collaborations network) and, secondly, an individual one (based on the Indegree score in the citations network). In the collaborations network, 43 authors $(10 \%)$ write exclusively alone, totaling 88 articles (37\% of the article data set). Some of these are central authors in the citations network (i.e., Eduardo Silva, Jessica Budds, David Carruthers, see Table 3).

From the collaborations network: researchers connect through 1000 edges (approximately 2.5 times the number of nodes). The network density is 0.012 and the cluster analysis yielded 77 communities with a modularity index of 0.895 . Figure 7 shows that there are many poorly connected communities, one community with over 35 actors, three communities with 20-30 actors, five communities with 10-15 actors, 16 with 5-10 actors, and, finally, 52 communities with less than five actors. The four biggest communities are the following.

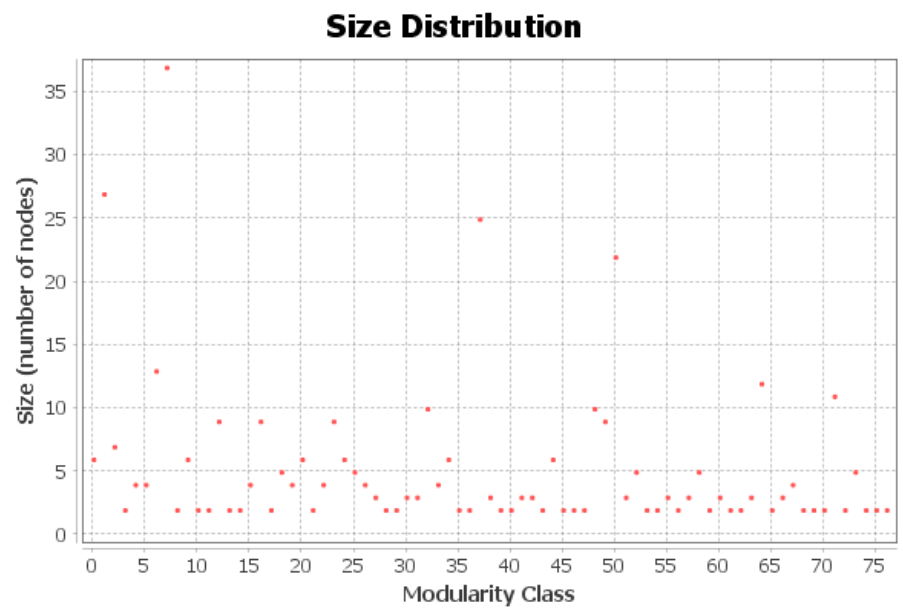

Figure 7. Communities' statistical distribution (modularity).

First is the Climate and Resilience Science Center or (CR)2 group (number 1 in Figure 8), a multidisciplinary and cross-universities group working around climate change, with five core authors in the EG/SG field: Gustavo Blanco Wells (Universidad Austral de Chile), Laura Nahuehual (Universidad Austral de Chile), Paulina Aldunce (Universidad de Chile) Raúl O'Ryan (Universidad Adolfo Ibañez) and Rodrigo Arriagada (Pontificia Universidad Católica de Chile, also director of the Center for the Socioeconomic Impact of Environmental Policies). The (CR) 2 was created in 2013, funded by the Fund for Financing Research Centers in Priority Areas (Fondap) of the National Commission for Scientific and Technological Research (formerly Conicyt, now ANID, Chile). The (CR)2 develops resilience and climate science in Chile, thus contributing to the country's goal of achieving low-carbon development, but also supporting adaptation and mitigation measures to build a society more resilient in the face of inevitable climate change.

Second, we find the CAPES/CCM group, with the Center of Applied Ecology and Sustainability and the Marine Conservation Center (number 2 in Figure 8). Both centers are focused on the conservation of marine ecosystems, whose membership draws overwhelmingly from the natural sciences, though a certain degree of dialogue exists with the social sciences. The CAPES/CCM group is structured around four core authors (all from the Pontificia Universidad Católica de Chile): Stefan Gelcich, Miriam Fernández, Natalio Godoy and Juan Carlos Castilla, all of whom have framed the topic of aquatic ecosystems from a governance perspective, largely through the analytical lens of the commons (drawing especially on the work of Elinor Ostrom, for example with the case of Territorial Use Rights for Fishing, TURF), but also through a critical analysis of Chilean marine ecosystems governance and contributions to the science-policy interface.

Thirdly, we find the LTER group (Long Term Environmental Research project, number 3 in Figure 8), which is the Southern cone subgroup of the long-term Socio-Ecological 
Studies program established in the United States during the 1980s to address problems which encompass decadal or longer time frames, and building an international network for the purposes of geographical comparison. In Chile, a group of biologists from the Institute of Ecology and Biodiversity (Ricardo Rozzi, Juan Armesto, Christopher Anderson and Julio Gutiérrez) adopted the LTER framework, focusing on biodiversity and conservation. The researchers in the LTER group are from different universities: Universidad de Chile, Pontificia Universidad Católica de Chile and Universidad Austral de Chile together with foreign universities from the USA (i.e., University of North Carolina, University of North Texas) and from Argentina (i.e., Universidad de Córdoba, Universidad de Buenos Aires), mainly connecting the natural and agricultural sciences.

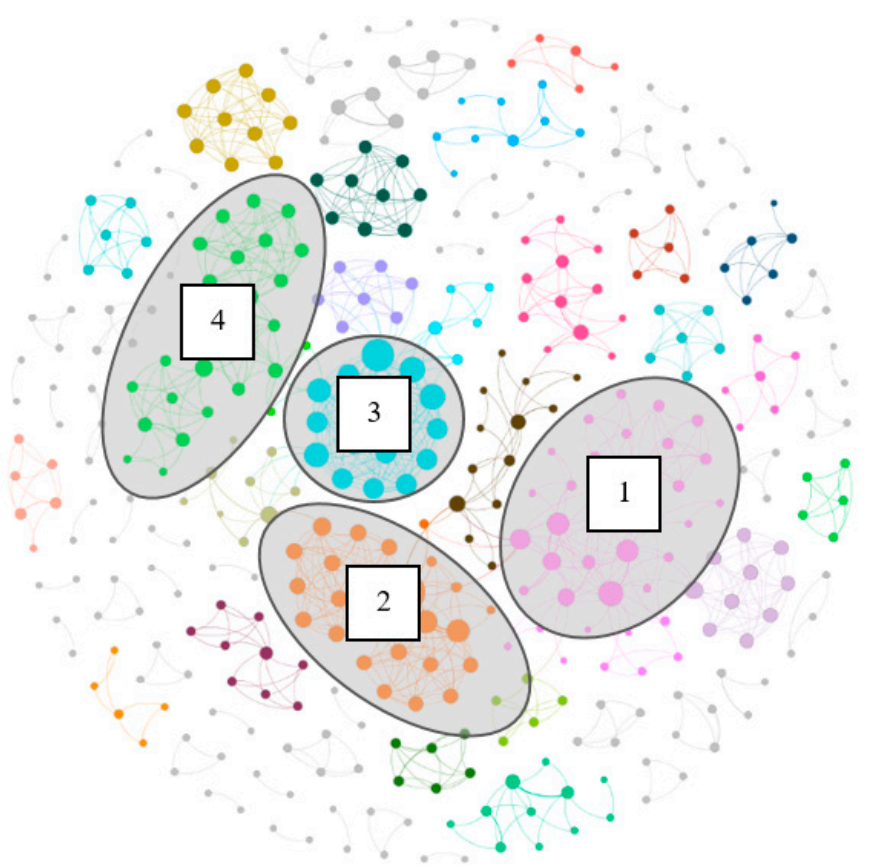

Figure 8. Collaborations Network by clusters. Number 1: Climate and Resilience Science Center; Number 2: CAPES/CCM group, with the Center of Applied Ecology and Sustainability and the Marine; Number 3: Conservation Center. LTER group (Long Term Environmental Research project); Number 4: the center-south of Chile.

Fourth, there is a group mainly from the agricultural sciences (especially forest engineering), from the center-south of Chile, number 4 in Figure 8), which focuses on ecosystems restauration, particularly forests. This community gathers researchers from Universidad Austral de Chile (i.e., Pablo Donoso, Cecilia Smith-Ramírez, Jan Bannister), Universidad de la Frontera (Andrés Fuentes-Ramírez, Rodrigo Vargas Gaete), Universidad de Concepción (Manuel Acevedo), and Universidad de Talca (Roberto Pizarro and members of the Technological Center for Environmental Hydrology); but also from foreign universities and institutes such as the Argentine INTA or the University of Arizona. The work of this center-southern group on ecosystems restauration includes governance of the conservation and recovery of natural forests, and more generally the management of and legislation around forests.

Regarding the centrality of authors (see Table 5, see algo Figure 6), we see that some members of core communities are among the main authors (Juan Armesto and Antonio Lara of LTER, Stefan Gelcich of CAPES/CCM), but most of the central actors are single authors, most being renowned foreign academics (such as Carl Bauer, Elinor Ostrom, Juan Carlos Castilla, Eric Swyngedouw, Eduardo Silva, Jessica Budds, or David Harvey) or foreign groups (e.g., Stockholm Resilience Center). The main disciplinary group is the social sciences $(73 \%)$, followed by the natural sciences $(20 \%)$ and agricultural sciences 
(7\%). Here we see how EG/GS issues rely on interdisciplinarity between social and natural sciences. Indeed, if the core communities we revised are populated mainly with researchers from the natural sciences, the citations pattern shows that they do engage in dialogue with the social sciences. Regarding their geographical distribution pattern, the major authors are from Chile (40\%), USA (40\%) and Europe (20\%).

Table 5. Top 15 major authors (ranked by weighted Indegree).

\begin{tabular}{|c|c|c|c|c|}
\hline Ranking & Authors & $\begin{array}{l}\text { Weighted } \\
\text { Indegree }\end{array}$ & Discipline & Institution \\
\hline 1 & Bauer C. & 87.37 & Social Sciences & University of Arizona \\
\hline 2 & Ostrom E. & 71.96 & Social Sciences & Indiana University \\
\hline 3 & Castilla J.C. & 71.57 & $\begin{array}{l}\text { Natural } \\
\text { Sciences }\end{array}$ & $\begin{array}{l}\text { Pontificia Universidad } \\
\text { Católica de Chile }\end{array}$ \\
\hline 4 & Folke C. & 67.56 & Social Sciences & Stockholm Resilience Center \\
\hline 5 & Lara A. & 61.9 & $\begin{array}{l}\text { Agricultural } \\
\text { Sciences }\end{array}$ & Universidad Austral Chile \\
\hline 6 & Sepulveda C. & 50.99 & Social Sciences & $\begin{array}{l}\text { University of British } \\
\text { Columbia }\end{array}$ \\
\hline 7 & Barton J. & 44.35 & Social Sciences & $\begin{array}{l}\text { Pontificia Universidad } \\
\text { Católica de Chile }\end{array}$ \\
\hline 8 & Gelcich S. & 43.63 & $\begin{array}{l}\text { Natural } \\
\text { Sciences }\end{array}$ & $\begin{array}{l}\text { Pontificia Universidad } \\
\text { Católica de Chile }\end{array}$ \\
\hline 9 & Swyngedouw E. & 37.01 & Social Sciences & University of Manchester \\
\hline 10 & Silva E. & 36.97 & Social Sciences & Tulane University \\
\hline 11 & Olsson P. & 34.72 & Social Sciences & Stockholm University \\
\hline 12 & Prieto M. & 34.67 & Social Sciences & $\begin{array}{l}\text { Pontificia Universidad } \\
\text { Católica de Chile }\end{array}$ \\
\hline 13 & Budds J. & 32.99 & Social Sciences & University of East Anglia \\
\hline 14 & Harvey D. & 32.98 & Social Sciences & City University of New York \\
\hline 15 & Armesto J. & 32.56 & $\begin{array}{l}\text { Natural } \\
\text { Sciences }\end{array}$ & $\begin{array}{l}\text { Pontificia Universidad } \\
\text { Católica de Chile }\end{array}$ \\
\hline
\end{tabular}

\subsection{Main Research Themes}

\subsubsection{Highly Cited References}

In academic production, the references account for the background foundations of any research. Analyzing the references cited allows us to grasp this background and capture the knowledge basis in any given field, as well as the central themes covered. Table 6 shows the 15 most cited references in EG/SG research in Chile, featuring five books, two reports, one piece of law, and seven journal articles (six articles from the data set). Apart from the two reports and the reference to Law 19.300 ("on the general bases of the environment"), all of these references share a critical position towards the clear-cut neoliberal development model adopted by Chile since Pinochet's dictatorship, which reduced environmental policy to the minimum in the name of an "economy-first" formula. We can classify the references into four categories: (a) Water governance, (b) Environmental policies and laws, (c) Sustainable aquaculture and globalization, and (d) Neoliberalism and governance.

Water governance is chiefly represented by the work of Carl Bauer from Arizona University [45-47], but also by Jessica Budds from the University of East Anglia [48], as well as by Axel Dourojeanni \& Andrei Jouravlev from the ECLAC Division of Natural Resources and Energy [49]. These studies focus on water governance in a neoliberal context, framing Chile as a social experiment in terms of its water privatization and market-based governance model. Authors in this category are mainly foreign and see Chile as the "blueprint for the neoliberal model" [46], where water has been commoditized via privatization and water markets, a blueprint based on an idealized theoretical economic model that is not consistent with socio-ecological reality and that conceals power imbalances and multiple conflicts over water. 
References related to environmental policies and laws frame issues in a similar vein to those relating to water governance. They portray a neoliberal economic model based on extractive activities and reveal a "disturbing underside to the Chilean miracle" [50], insofar as environmental politics and laws remain hostage to a legal framework inherited from Pinochet's dictatorship and to an economic orthodoxy inimical to sustainability [51,52]. Consequently, the type of environmental governance observable in Chile "expresses a strongly market-enabling quality instead of the market-regulating character commonly ascribed to environmental law and policy" [53], which inhibits the emergence of a strong SG, and maintains strong pressures over ecosystems [54], as evidenced in many of the works in our data set of articles.

Table 6. Top 15 highly cited references.

\begin{tabular}{|c|c|c|c|c|}
\hline Frequency & Authors & Year & Title & Source \\
\hline 18 & Bauer C. & 1998 & $\begin{array}{l}\text { Against the current: Privatization water } \\
\text { markets and the state in Chile }\end{array}$ & $\begin{array}{l}\text { University of California } \\
\text { at Berkeley }\end{array}$ \\
\hline 17 & Carruthers D. & 2001 & $\begin{array}{l}\text { Environmental politics in Chile: legacies } \\
\text { of dictatorship and democracy. }\end{array}$ & Third World Quarterly \\
\hline 16 & $\begin{array}{l}\text { Tecklin D., Bauer C. \& } \\
\text { Prieto M. }\end{array}$ & 2011 & $\begin{array}{l}\text { Making environmental law for the market: } \\
\text { the emergence, character, and implications } \\
\text { of Chile's environmental regime. }\end{array}$ & Environmental Politics \\
\hline 15 & OECD \& ECLAC & 2005 & $\begin{array}{l}\text { OECD environmental performance } \\
\text { reviews- Chile }\end{array}$ & OECD \& ECLAC \\
\hline 14 & Bauer C. & 2004 & $\begin{array}{l}\text { Siren Song: Chilean Water Law as a } \\
\text { Model for International Reform }\end{array}$ & Resources for the Future \\
\hline 14 & IPCC & 2007 & $\begin{array}{l}\text { Fourth Assessment Report on Climate } \\
\text { Change }\end{array}$ & IPCC \\
\hline 14 & Chile Government & 1994 & $\begin{array}{c}\text { Law } 19.300 \text { of the general bases of the } \\
\text { environment }\end{array}$ & Chile Government \\
\hline 12 & Silva E. & 1996 & $\begin{array}{l}\text { Democracy, Market Economics, and } \\
\text { Environmental Policy in Chile }\end{array}$ & $\begin{array}{c}\text { Journal of Interamerican } \\
\text { Studies and World } \\
\text { Affairs }\end{array}$ \\
\hline 11 & Camus P. \& Hajek E. & 1998 & Historia ambiental de Chile & $\begin{array}{l}\text { Pontificia Universidad } \\
\text { Católica de Chile }\end{array}$ \\
\hline 11 & Barton J. \& Floysand A. & 2010 & $\begin{array}{c}\text { The political ecology of Chilean salmon } \\
\text { aquaculture, 1982-2010 }\end{array}$ & $\begin{array}{l}\text { Global Environmental } \\
\text { Change }\end{array}$ \\
\hline 11 & Bauer C. & 1997 & $\begin{array}{l}\text { Bringing water markets down to earth. } \\
\text { The political economy of water rights in } \\
\text { Chile, 1976-1995. }\end{array}$ & World Development \\
\hline 11 & Budds J. & 2004 & $\begin{array}{l}\text { Power, Nature and Neoliberalism: The } \\
\text { Political Ecology of Water in Chile. }\end{array}$ & $\begin{array}{c}\text { School of Geography and } \\
\text { the Environment }\end{array}$ \\
\hline 10 & Harvey D. & 2005 & A brief history of neoliberalism & Oxford University Press \\
\hline 9 & Ostrom E. & 1990 & $\begin{array}{l}\text { Governing the Commons: The Evolution } \\
\text { of Institutions for Collective Action }\end{array}$ & $\begin{array}{c}\text { Cambridge University } \\
\text { Press }\end{array}$ \\
\hline 9 & $\begin{array}{l}\text { Dourojeanni A. \& } \\
\text { Jouralvev A. }\end{array}$ & 1999 & $\begin{array}{l}\text { El código de aguas en Chile: entre la } \\
\text { ideología y la realidad }\end{array}$ & ECLAC \\
\hline
\end{tabular}

A central article specifically focusing on the political ecology of Chilean salmon aquaculture [55], as a case of non-traditional export-oriented activities, draws a balance between positive and negative effects of the increasing globalization of this sector. Like other central references, Barton \& Fløysand adopt a political ecology approach to analyze actors, rationalities, norms, infrastructures, decision-making and power relations in the sector. As mentioned before, salmon aquaculture has grown in importance as a research topic (classified within "aquatic ecosystems" in the topics analysis), especially after the ISA virus crisis in 2007, which strongly affected the salmon culture industry in Chile. Thus it became a central subtopic, with much of the research, (see among others, [56,57]) being similarly conducted from the vantage point of political ecology, and pointing out the weakness of environmental governance in a strong neoliberal context. 
Finally, there are other central references that are general reports on the state of the environment in Chile [58], and on global climate change [59]. There are also some "classical" theoretical references on critical analysis of neoliberalism [60] and governance of the commons [61], which provide theoretical support to the analysis of the dominant economic model (at the macro level) and to the alternative institutional arrangements structured by local actors (at the micro level).

An analysis of the top cited references allowed us to identify the central topics, yielding insights consistent with our deductive analysis (see point 3.1. General statistics of the data set). Yet, at the same time, it conceals the bigger picture of the topics covered in the field, more specifically, of emergent core topics such as climate change and energy. For this reason, we undertook an in-depth analysis of main research themes based on an inductive analysis of keywords' frequency and co-occurrence.

\subsubsection{Keywords' Frequency and Co-Occurrence}

The function of keywords in academic texts, along with the abstract, is to condense the relevance of the text to a wider audience. Our network analysis of keywords frequency and co-occurrence allowed us to identify topical foci which are central to the entire field of EG/SG in Chile through an inductive approach, helping to refine the deductive analysis developed in Section 3.1. Figure 9 shows the network of relations among keywords, based on the co-occurrence of keywords in the corpus. The size of each node indicates the frequency with which the keywords appear, and the edge between each pair of nodes indicates the co-occurrence between keywords. As expected, given the type of query carried out to account for the academic production on EG/SG in Chile, the keywords "Governance", "Environment", "Sustainability", "Environmental governance" and "Public Policy" appear as the core concepts structuring the field. However, and more unexpectedly, "neoliberalism" also features among the core concepts, insofar a major target of criticism as a mode of environmental governance in Chile (as we see for example with highly cited references analysis); so does "political ecology", in close relation to water-related themes (from water governance in general to salmon aquaculture). Apart from these, we also retrieved the main topics covered by deductive analysis (see Figure 10), with climate change featuring prominently (including adaptation/mitigation and resilience approaches), but also topics such as water, agriculture, and especially energy. Indeed, climate change overlaps with the topic of energy, insofar as clean energy transition strategies appear as a key response to climate change. We also found three main topics directly connected to the central academic communities identified above (see point 3.4. Analysis of central groups and authors): The Long-Term Environmental Research group, Biodiversity Conservation, and the broad topic of Environmental Policies and Laws (present in highly cited references analysis). Besides, we found two new topics: "Environmental Conflicts/Environmental Justice" (strongly associated with environmental policies and laws and directly connected to the issue of broadening participation in environmental governance); and "Knowledge for Environmental Governance" (particularly the "science-policy interface"). 


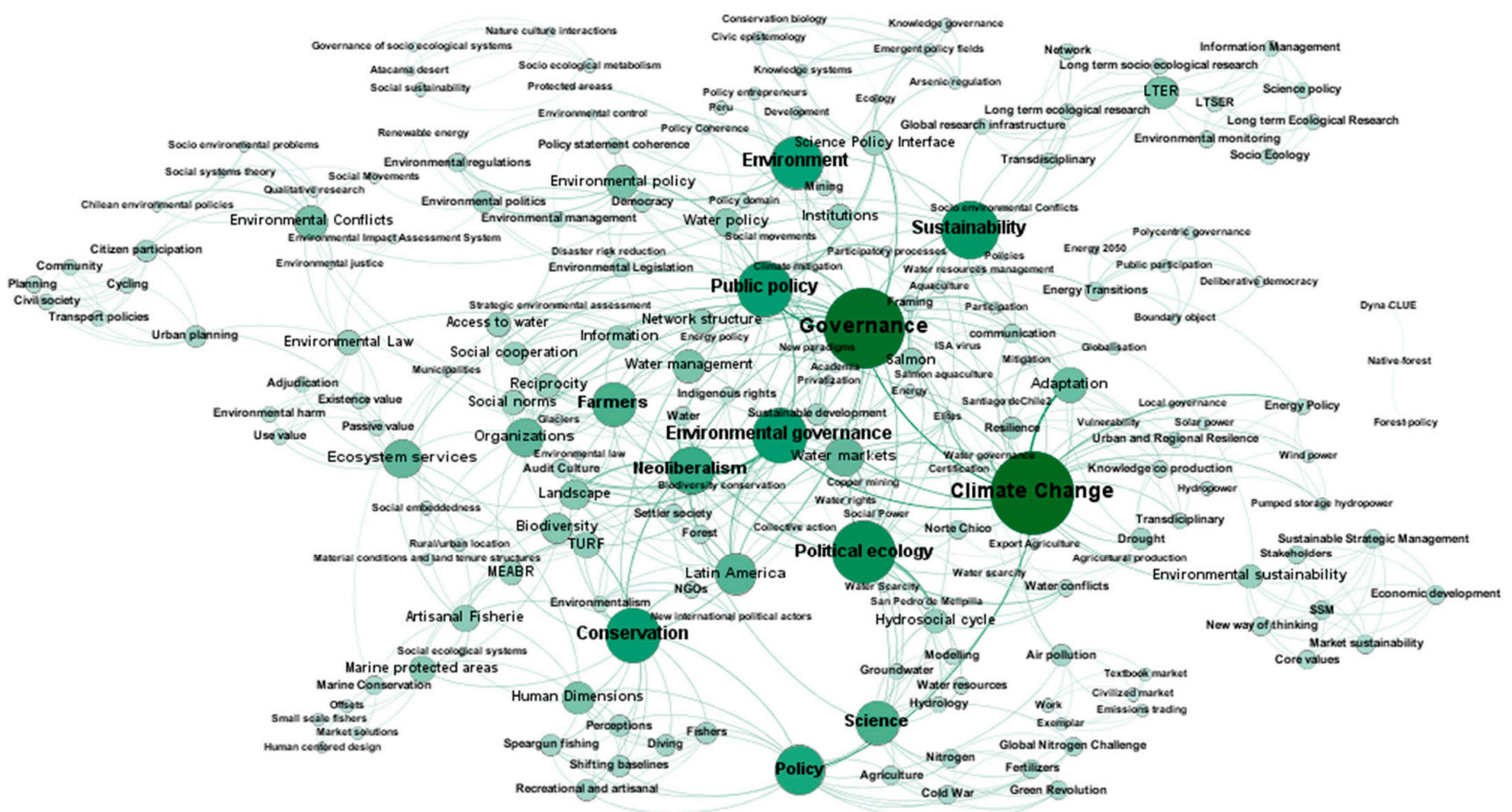

Figure 9. Keywords co-occurrences. (Network built on the basis of co-occurrence of keywords in texts from the data set. This is an undirected graph generated with the centrality and proximity algorithm Force Atlas 2 [44]. The size and color of the nodes varies depending on their degree).

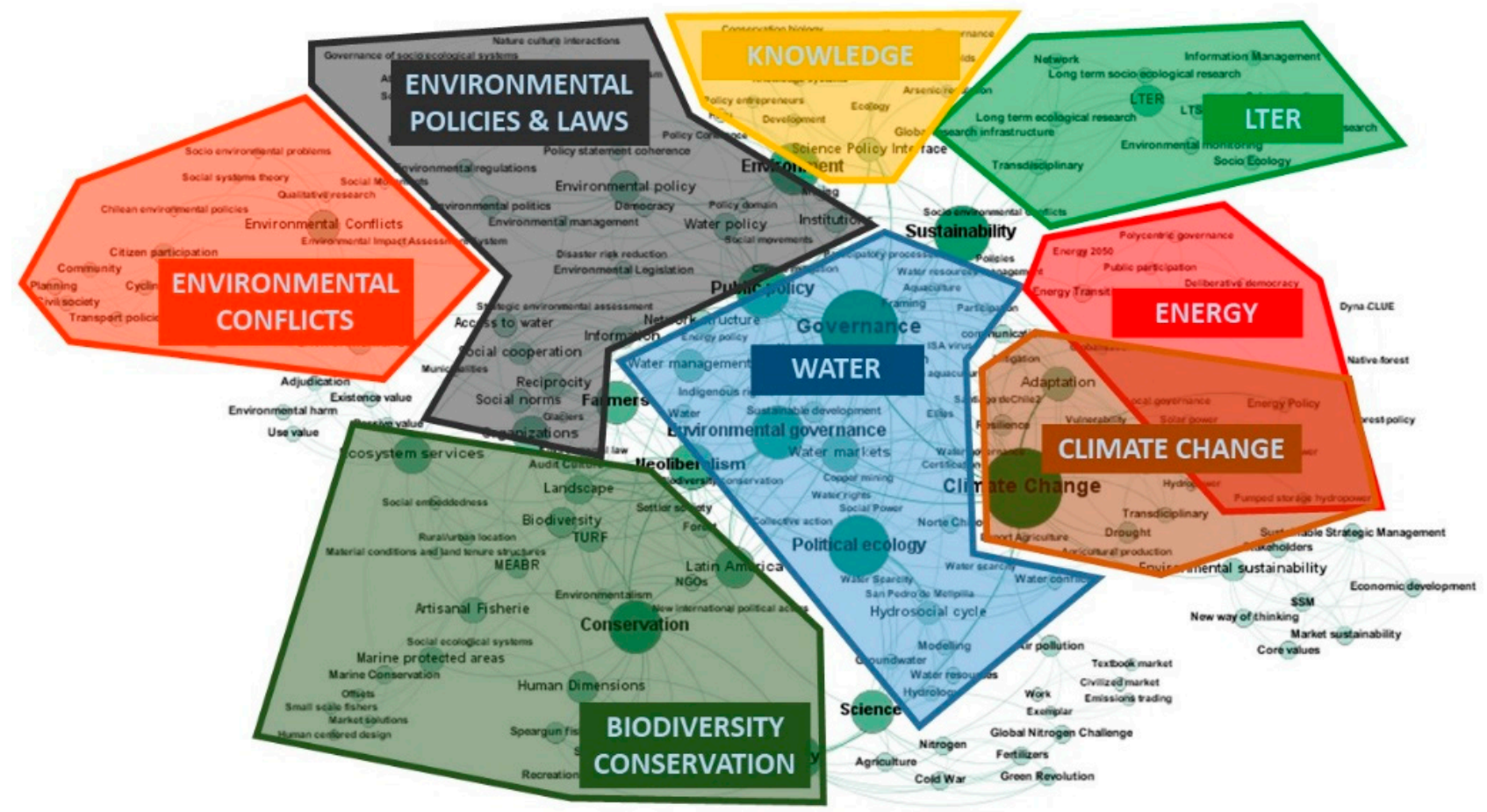

Figure 10. Topical landscape from keyword co-occurrences.

\section{Discussion}

As we can see from the data analyzed, the EG/SG research agenda in Chile intertwines topics of the global EG agenda (i.e., climate change, energy, biodiversity) with the particularities emerging from local reality, especially around the Chilean economic matrix 
(i.e., large-scale mining, fisheries and salmon aquaculture, forests, agriculture) and from local institutions and laws. Indeed, the EG/SG research field has developed in parallel to the consolidation of an environmental institutional and policy framework in Chile, which have served as catalyzer of national public debates around the environment. Examples include the environmental impacts of industrial projects, the (re)design of environmental institutions, but also more specific or sectoral issues, such as the ISA virus crisis, air pollution in megacities, and the recent definitions around long-term strategic environmental governance, such as the framework law for waste management, the extended responsibility of the producer, the promotion of recycling, or Chile's energy policy, Energía 2050.

The academic community thus participates in public debates as an actor in environmental governance, albeit less in the role of informing public policies than in that of critically analyzing them with regard to their impact on ecosystems, although in recent years there has been a growing interest in the science-policy interface around EG. In sum, the major research topics are directly connected with the modes of production, impacts on ecosystems, and environmental policy and laws.

Our analysis provides a solid, databased overview of the research field on EG/SG in Chile, including its main knowledge producers and references (both academic communities and single authors). Furthermore, it also provides insight into the field dynamics, e.g., the degree of internationalization of EG/SG research or its patterns of collaboration. This provides clues as to, for example, how exo- or endogamic the field dynamics and groupings are; or if collaborations organize around specific projects, research platforms or institutions, which works as a proxy to infer the weight of third-party funding in shaping research agendas.

As interesting as what the data analysis renders visible, however, is what it reveals as invisible. Regarding the research topoi, as well as disciplinary fault lines, our analysis shows interdisciplinary collaboration between the natural and the social sciences. On closer inspection, however, the field clearly reveals itself as structured around natural science criteria, that is, around particular ecosystems, such as marine or forest, or the climate system; or else around discrete foci on specific economic sectors or resources (water, aquaculture, energy production, etc.). Missing from the picture are cross-cutting socioeconomic and cultural dynamics shaping prevalent yet fundamentally unsustainable ways of life (individualistic, resource-intensive high consumption) or modes of socio-economic organization (production, consumption, distribution, and disposal patterns; trans-territorial socio-ecological metabolism; the growth-dependency of social infrastructures such as pension funds or public health services, and their environmental impact, to mention but a few). A social science framing, in turn, would focus on issues such as historical and contextual complexities, conditions and visions for social-ecological change, and the role of interpretation, sense-making, and identity-building, together with the emerging political and cultural implications [62]. This does not necessarily imply that such studies do not exist in Chile, but rather that if they existed, they are not prominently conducted under the header of "environmental" or "sustainability" governance, which is telling in and of itself.

Furthermore, while the critique of neoliberal governance arrangements and institutions is pervasive across the data set, alternative approaches or experimental forms of socio-ecological organization, at least at the meso- and macro-societal level, are notoriously absent. With the exception of Elinor Ostrom's commons governance framework, which features somewhat prominently in the data set (though restricted to the silo of aquatic ecosystems governance), notions of non- or post-capitalist economic organization, work and time regimes or other increasingly controversial political economy topoi such as GDP growth-dependence, income and wealth distribution or transnational resource flows could not be derived from the data. It might be contended that the proposed orientations belong to the realms of political economy, socio-technical studies or even to cultural studies, rather than to that of environmental sustainability. A growing body of literature, however, argues in the opposite sense. 
The challenges of achieving much stronger sustainability governance in the sociopolitical sphere are accompanied by the need for scholars to rethink dominant ideas about how to achieve sustainability. Transformative perspectives on sustainability require critical inquiry, which demands that we do not take the current world order as a given and try to find solutions within already established economic, social and political parameters. Rather, we have to inquire into these parameters in order to better understand how this particular world came about and why, and what its material and ideational structures imply for the potential and characteristics of sustainability transformation. In other words, global sustainability governance cannot perform the role of steering human societies towards "environmental and social sustainability" without questioning the broader, deeper causes underlying the major sustainability challenges that we are experiencing and without debating who defines and benefits from the proposed solutions [7].

\section{Conclusions}

Based on bibliometric and network analysis, this study reviewed the academic production on EG/SG in Chile from 1993 to 2018, contributing to an understanding of the structuration of EG/SG academic field in Chile. Due to the model role of the country in Latin-American EG/SG, this also provides relevant insight into the regulative ideals of EG/SG research at regional-international scale, providing guidance for future research. The main conclusions are as follows.

First (RQ1a and RQ2), our analysis shows that the academic production on EG/SG in Chile experienced a significant increase since the 1990s, with a high dispersion in international publication platforms (journals), which are, however, largely concentrated in geographical terms: the United Kingdom (25\%), Chile (23\%), United States (17\%) and Netherlands (13\%). EG/SG in Chile represents a multidisciplinary field (RQ3c), despite the fact that collaboration networks show a closer dialogue pattern within disciplinary clusters (see Figure 6), particularly between the natural and the agricultural sciences with engineering, as well as single-discipline groups (mainly from the social sciences, but also engineering).

At the collaboration level, we find some core academic communities (RQ2, RQ3a and RQ3b); particularly, four of them are working on climate change (CR2, a strategic academic center producing data for Chile), conservation of marine ecosystems (CAPES/CCM, including the analysis of sustainable use of sea resources and critical analysis of Chilean marine ecosystems governance with some contributions to the science-policy interface), the Southern cone subgroup of the Long-Term Socio-Ecological Studies program (LTER), and, finally, a group from the center-south of the country which focuses on forest restauration.

Regarding core authors (RQ2), some members of above-identified communities take center-stage (i.e., Juan Armesto and Antonio Lara of LTER, Stefan Gelcich of CAPES/CCM) but most of the central figures are single, internationally renowned authors (such as Carl Bauer, Elinor Ostrom, Juan Carlos Castilla, Eric Swyngedouw, Eduardo Silva, Jessica Budds, or David Harvey) or foreign research organizations (such as the Stockholm Resilience Center).

With regard to research topics (RQ1b), there are consistent results between different types of analysis, which enables us to underline some core research topoi: water governance (including water markets, water rights, but also an important political ecology approach to water, for example regarding salmon aquaculture and hydro-energy); environmental policies and laws (i.e., the political and juridical mainstreaming of environmental issues in Chile and its problematic embeddedness in a neoliberal economic model); climate change, which overlaps with energy and biodiversity conservation; as well as research on environmental conflicts and justice (including the central issue of stakeholder participation in environmental governance).

However, our analysis also reveals a significant bias in the conceptual framing of governance for social-ecological sustainability, in that "environmental governance" is defined in terms of discrete ecosystems, resources, or economic sectors or projects, while the key 
underlying issue of unsustainable modes of life and of economic organization (including models of political economy, social-ecological metabolism, and consumerist imaginaries, among others) remaining unaddressed. By current standards of global knowledge, this selective blindness must be regarded as highly problematic, as it reinforces the nature-society dualism and, with it, the corollary that lifeworld sustainability can be decoupled, in the long run, from system sustainability. Insofar as they have a direct impact on the sphere of EG/SG-be it by influencing the policy sphere or by informing sociopolitical critique of current policy orientations-scholars do have a central role to play in reimagining ways to achieve socio-ecological sustainability in line with the insights from state-of-the-art research on sustainability transformations.

Author Contributions: Conceptualization, J.V. \& A.E.B.; methodology and results, J.V.; discussion and conclusion, A.E.B. \& J.V. Both authors have read and agreed to the published version of the manuscript.

Funding: This research was funded by the National Agency of Research and Development of Chile (ANID), Fondecyt Program, grant number 11180256.

Institutional Review Board Statement: Not applicable.

Informed Consent Statement: Not applicable.

Data Availability Statement: We use data retrieved from the databases mentioned. Data sharing is not applicable to this article.

Conflicts of Interest: The authors declare no conflict of interest.

\section{References}

1. Arnason, J.P. Praxis and Action-Mainstream Theories and Marxian Correctives. Thesis Eleven 1991, 29, 63-81. [CrossRef]

2. Wagner, P. Modernity as Experience and Interpretation: A New Sociology of Modernity; Polity: Cambridge, UK, 2008; ISBN 978-0-7456-4218-5.

3. Kooiman, J. Governing as Governance; SAGE: Newcastle upon Tyne, UK, 2003; ISBN 978-0-85702-180-9.

4. Adger, W.N.; Jordan, A. Governing Sustainability; Cambridge University Press: Cambridge, UK, 2009; ISBN 978-1-316-10416-3.

5. Folke, C.; Hahn, T.; Olsson, P.; Norberg, J. Adaptive Governance of Social-Ecological Systems. Annu. Rev. Environ. Resour. 2005, 30, 441-473. [CrossRef]

6. Lemos, M.C.; Agrawal, A. Environmental Governance. Annu. Rev. Environ. Resour. 2006, 31, 297-325. [CrossRef]

7. Kalfagianni, A.; Fuchs, D.; Hayden, A. Routledge Handbook of Global Sustainability Governance; Routledge: Abingdon, VA, USA, 2019; ISBN 978-1-351-69129-1.

8. Biermann, F. The Future of 'Environmental' Policy in the Anthropocene: Time for a Paradigm Shift. Environ. Polit. 2021, 30, 61-80. [CrossRef]

9. Dobson, A. Green Political Thought, 3rd ed.; Routledge: Abingdon, VA, USA, 2002; ISBN 978-0-203-13167-1.

10. Dryzek, J.S. The Politics of the Earth: Environmental Discourses; Oxford University Press: Oxford, UK, 1997; ISBN 978-0-19-878160-8.

11. Steffen, W.; Richardson, K.; Rockström, J.; Cornell, S.E.; Fetzer, I.; Bennett, E.M.; Biggs, R.; Carpenter, S.R.; de Vries, W.; de Wit, C.A.; et al. Planetary Boundaries: Guiding Human Development on a Changing Planet. Science 2015, 1259855. [CrossRef]

12. Chakrabarty, D. The Human Condition in the Anthropocene. In The Tanner Lectures in Human Values; Harvard University Press: Cambridge, MA, USA, 2015.

13. Crutzen, P.J.; Stoermer, E. The "Anthropocene". Glob. Chang. Newsl. 2000, 17-18.

14. McNeill, J.R.; Engelke, P. The Great Acceleration: An Environmental History of the Anthropocene Since 1945; Harvard University Press: Cambridge, MA, USA, 2016; ISBN 978-0-674-54503-8.

15. Hausknost, D. The Environmental State and the Glass Ceiling of Transformation. Environ. Polit. 2020, 29, 17-37. [CrossRef]

16. Jänicke, M.; Jörgens, H. New Approaches to Environmental Governance. In Environmental Governance in Global Perspective: New Approaches to Ecological Modernisation; Jänicke, M., Jacob, K., Eds.; Routledge: Abingdon, VA, USA, 2020; pp. 167-209, ISBN 978-1-00-306106-9.

17. Weale, A. Governance, government and the pursuit of sustainability. In Governing Sustainability; Adger, W.N., Jordan, A., Eds.; Cambridge University Press: Cambridge, UK, 2009; pp. 55-75, ISBN 978-1-316-10416-3.

18. Lebel, L.; Anderies, J.M.; Campbell, B.; Folke, C.; Hatfield-Dodds, S.; Hughes, T.P.; Wilson, J. Governance and the Capacity to Manage Resilience in Regional Social-Ecological Systems. Ecol. Soc. 2006, 11, 19. [CrossRef]

19. Sapat, A. Routledge Handbook of Environmental Governance; Taylor \& Francis Group: Hoboken, NJ, USA, 2017; ISBN 978-1-138-92050-7.

20. Biermann, F. Earth System Governance: World Politics in the Anthropocene; The MIT Press: Cambridge, MA, USA, 2014; ISBN 978-0-262-52669-2. 
21. UN Environment (Ed.) Global Environment Outlook-GEO-6: Summary for Policymakers; Cambridge University Press: Cambridge, UK, 2019; ISBN 978-1-108-70768-8.

22. Schaffartzik, A.; Mayer, A.; Gingrich, S.; Eisenmenger, N.; Loy, C.; Krausmann, F. The Global Metabolic Transition: Regional Patterns and Trends of Global Material Flows, 1950-2010. Glob. Environ. Chang. 2014, 26, 87-97. [CrossRef]

23. Fischer-Kowalski, M.; Krausmann, F.; Pallua, I. A Sociometabolic Reading of the Anthropocene: Modes of Subsistence, Population Size and Human Impact on Earth. Anthr. Rev. 2014, 1, 8-33. [CrossRef]

24. Biermann, F.; Pattberg, P.H. Global Environmental Governance Reconsidered; MIT Press: Cambridge, MA, USA, 2012; ISBN 978-0-26251770-6.

25. Managers of Global Change: The Influence of International Environmental Bureaucracies; Biermann, F.; Siebenhüner, B. (Eds.) MIT Press: Cambridge, MA, USA, 2009; ISBN 978-0-262-01274-4.

26. Kumar, R. The United Nations and Global Environmental Governance. Strateg. Anal. 2020, 44, 479-489. [CrossRef]

27. Aykut, S.C.; Dahan, A. Gouverner le Climat?: Vingt ans de Négociations Internationales; Presses de Sciences Po: Paris, France, 2014; ISBN 978-2-7246-1680-4.

28. Governing Global Biodiversity: The Evolution and Implementation of the Convention on Biological Diversity; Le Prestre, P.G. (Ed.) Routledge: Abingdon, VA, USA, 2017; ISBN 978-1-351-93253-0.

29. McCarthy, J. Privatizing Conditions of Production: Trade Agreements as Neoliberal Environmental Governance. Geoforum 2004, 35, 327-341. [CrossRef]

30. Borgatti, S.P.; Everett, M.G.; Johnson, J.C. Analyzing Social Networks; SAGE: Newcastle upon Tyne, UK, 2018; ISBN 978-1-5264-1846-3.

31. Wasserman, S.; Faust, K. Social Network Analysis: Methods and Applications; Cambridge University Press: Cambridge, UK, 1994; ISBN 978-0-521-38707-1.

32. De Bellis, N. Bibliometrics and Citation Analysis: From the Science Citation Index to Cybermetrics; Scarecrow Press: Lanham, MD, USA, 2009; ISBN 978-0-8108-6714-7.

33. Padilla-Navarro, P.; Vallejos-Romero, A. Ciencias agrarias chilenas entre 1989 y 2016: Redes, colaboración científica y comunidades de investigación. Rev. Esp. Doc. Científica 2020, 43, e273. [CrossRef]

34. Barandiarán, J. The Authority of Rules in Chile's Contentious Environmental Politics. Environ. Polit. 2016, 25, 1013-1033. [CrossRef]

35. Maillet, A.; Carrasco, S. 30 años de institucionalidad ambiental en Chile: Entre la esperanza y las promesas incumplidas (1990-2018). In Chile y el Cambio Climático. Pensar Globalmente, Actuar Localmente; Carrasco Hidalgo, C., Ed.; Friedrich Ebert Stiftung-Transformación Social Ecológica: Mexico City, Mexico, 2019; pp. 66-92, ISBN 978-607-8642-22-9.

36. Estenssoro, F.; Vásquez, J.P.V. Perspectivas políticas ambientales latinoamericanas. Los casos Chile, Ecuador y Brasil entre Río-92 y Río+20. Rev. Estud. Hemisféricos Polares 2018, 9, 1-26.

37. Haunschild, R.; Bornmann, L.; Marx, W. Climate Change Research in View of Bibliometrics. PLoS ONE 2016, 11, e0160393. [CrossRef]

38. Sapiains, R.; Ibarra, C.; Jiménez, G.; O’Ryan, R.; Blanco, G.; Moraga, P.; Rojas, M. Exploring the Contours of Climate Governance: An Interdisciplinary Systematic Literature Review from a Southern Perspective. Environ. Policy Gov. 2021, 31, 46-59. [CrossRef]

39. Vanhulst, J.; Zaccai, E. Sustainability in Latin America: An Analysis of the Academic Discursive Field. Environ. Dev. 2016, 20, 68-82. [CrossRef]

40. Beigel, F. Centros y Periferias En La Circulación Internacional Del Conocimiento. Nueva Soc. 2013, 110-124.

41. Narvaez-Berthelemot, N.; Frigoletto, L.P.; Miquel, J.F. International Scientific Collaboration in Latin America. Scientometrics 1992, 24, 373-392. [CrossRef]

42. Fruchterman, T.M.J.; Reingold, E.M. Graph Drawing by Force-Directed Placement. Softw. Pract. Exp. 1991, 21, 1129-1164. [CrossRef]

43. OECD. Frascati Manual 2015: Guidelines for Collecting and Reporting Data on Research and Experimental Development; OECD: Paris, France, 2015; ISBN 978-92-64-23880-0.

44. Jacomy, M.; Venturini, T.; Heymann, S.; Bastian, M. ForceAtlas2, a Continuous Graph Layout Algorithm for Handy Network Visualization Designed for the Gephi Software. PLoS ONE 2014, 9, e98679. [CrossRef] [PubMed]

45. Bauer, C. Slippery Property Rights: Multiple Water Uses and the Neoliberal Model in Chile, 1981-1995. Nat. Resour. J. 1998, 38, 109-155.

46. Bauer, C.J. Against the Current?: Privatization, Markets, and the State in Water Rights: Chile, 1979-1993; University of California: Berkeley, CA, USA, 1995.

47. Bauer, C.J. Siren Song: Chilean Water Law as a Model for International Reform; Resources for the Future: Washington, DC, USA, 2004; ISBN 978-1-891853-79-1.

48. Budds, J. Power, Nature and Neoliberalism: The Political Ecology of Water in Chile. Singap. J. Trop. Geogr. 2004, 25, 322-342. [CrossRef]

49. Dourojeanni, A.; Jouravlev, A. El Código de Aguas de Chile:Entre La Ideología y La Realidad; Serie Recursos Naturales e Infraestructura; ECLAC: Santiago de Chile, Chile, 1999; p. 84.

50. Carruthers, D. Environmental Politics in Chile: Legacies of Dictatorship and Democracy. Third World Q. 2001, 22, 343-358.

51. Silva, E. Democracy, Market Economics, and Environmental Policy in Chile. J. Interam. Stud. World Aff. 1996, 38, 1-33. [CrossRef]

52. Camus, P.; Hajek, E. Historia Ambiental de Chile; Pontificia Universidad Catolica de Chile: Santiago de Chile, Chile, 1998. 
53. Tecklin, D.; Bauer, C.; Prieto, M. Making Environmental Law for the Market: The Emergence, Character, and Implications of Chile's Environmental Regime. Environ. Polit. 2011, 20, 879-898. [CrossRef]

54. Instituto de Asuntos Públicos. Informe País. Estado Del Medio Ambiente En Chile. Comparación 1999-2015; Universidad de Chile: Santiago de Chile, Chile, 2016; p. 605.

55. Barton, J.R.; Fløysand, A. The Political Ecology of Chilean Salmon Aquaculture, 1982-2010: A Trajectory from Economic Development to Global Sustainability. Glob. Environ. Chang. 2010, 20, 739-752. [CrossRef]

56. Bustos-Gallardo, B. The ISA Crisis in Los Lagos Chile: A Failure of Neoliberal Environmental Governance? Geoforum 2013, 48, 196-206. [CrossRef]

57. Bustos-Gallardo, B.; Irarrazaval, F. "Throwing Money into the Sea": Capitalism as a World-Ecological System. Evidence from the Chilean Salmon Industry Crisis, 2008. Capital. Nat. Social. 2016, 27, 83-102. [CrossRef]

58. OECD; CEPAL. OCDE Environmental Performance Reviews-Chile; OECD Publishing: Paris, France, 2005.

59. IPCC. Synthesis Report of the IPCC Fourth Assessment Report; Intergovernmental Panel on Climate Change: Geneva, Switzerland, 2007.

60. Harvey, D. A Brief History of Neoliberalism; OUP Oxford: Oxford, UK, 2007; ISBN 978-0-19-162294-6.

61. Ostrom, E. Governing the Commons: The Evolution of Institutions for Collective Action; Cambridge University Press: Cambridge, UK, 1990; ISBN 978-1-933771-77-9.

62. Hackmann, H.; St. Clair, A.L. Transformative Cornerstones of Social Science Research for Global Change; International Social Science Council: Paris, France, 2012. 